\title{
REPRESENTASI MUSIK SEBAGAI SEBUAH IDEOLOGI DI PEsaNTREN DALAM FILM BAM-BAIK SAYANG
}

\section{THE REPRESENTATION OF MUSIC AS AN IDEOLOGY OF PESANTREN IN MOVIEBAIK-BAIK SAYANG}

\author{
Dzulfikar Al-anbiya, Aquarini Priyatna, R.M. Mulyadi \\ Program Studi Kajian Budaya, Fakultas Ilmu Budaya, Universitas Padjadjaran \\ Jln. Raya Bandung Sumedang KM.21 \\ e-mail: d7u1fik4r@gmail.com, aquarini@unpad.ac.id,r.m.mulyadi@unpad.ac.id
}

\begin{abstract}
Abstrak
Artikel ini membahas musik di pesantren yang direpresentasikan sebagai sebuah ideology dalam film Baik-Baik Sayang.Perdebatan ideologi yang membolehkan dan melarang musik masih diperdebatkan di kalangan ulama dapat diargumentasikan sebagai manifestasi ideologi sebuah instansi pendidikan berbasis agama Islam tertentu. Perdebatan ideologi tersebut direpresentasikan dalam film Baik-Baik Sayang dengan mengangkat cerita perjalanan sebuah band musik bernama Wali yang dibentuk di Pesantren La Tansa. Penelitian ini menggunakan pendekatan kualitatif dengan konsep media representasi Stuart Hal dan kajian sinema. Penelitian ini menunjukkan bahwa film merepresentasikan musik sebagai ideologi secara biner. La Tansa dan Band Wali merupakan representasi ideologi yang membolehkan musik di pesantren. Ideologi yang berlawanan direpresentasikan melalui tokoh antagonis. Film juga merepresentasikan fenomena bentuk ideologi lain yang lebih negosiatif dalam sosok ayah $\mathrm{Fa}$ 'ank.
\end{abstract}

Kata kunci: ideologi, representasi, pesantren, musik.

\begin{abstract}
This article discusses music at the pesantren which is represented as an ideology in the film Baik-Baik Sayang. The ideological debate that allows and prohibits music is still debated among ulama can be argued as an ideological manifestation of a particular Islamic-based educational institution. The ideological debate is represented in the film Baik-Baik Sayang by raising the story of the journey of a music band called Wali which was formed at the Pesantren La Tansa. This study uses a qualitative approach using the concept of media representation Stuart Hal and the study of cinema. This research shows that film represents music as an ideology in a binary manner. La Tansa and Band Wali are ideological representations that allowing music in pesantren. The opposite ideology is represented by an antagonist. The film also represents another more negotiative ideological phenomenon in Ayah Fa'ank.
\end{abstract}

Keywords: ideology, representation, pesantren, music.

\section{A. PENDAHULUAN}

Artikel ini membahas bagaimana hukum memainkan dan mendengarkan musik di pesantren direpresentasikan sebagai sebuah ideology dalam film BaikBaik Sayang.Film ini bukan merupakan peraih penghargaan maupun film dengan angka penjualan tinggi. Namun, film ini dipilih karena di dalamya terdapat perdebatan mengenai isu membolehkan dan melarang memainkan, mendengarkan musik di pesantren.

Pada konteks hukum agama Islam atau syari'at (halal dan haramnya) musik 
masih diperdebatkan. Perdebatan tersebut terjadi karena adanya pandangan sebagian ulama yang membolehkan dan sebagian yang melarang mendengarkan dan memainkan musik. Azra (1997) pada kata pengantar buku Majid Bilik-Bilik Pesantren menyebutkan bahwa kaum salafiy $^{l}$ yang sering mengkritik pesantren. Kritik tersebut dilakukan karena pesantren yang dekat dengan tasawuf dan thariqat selalu melakukan $b i d ' a h^{2}$. Lebih spesifik lagi, kaum salafiy melarang segala bentuk pengajaran yang jauh dari ajaran rasul atau Nabi Muhammad. Mereka memandang musik bukan berasal dari ajaran dan contoh Nabi. Namun, sebagian ulama yang lain membolehkan memainkan dan mendengarkan musik dalam kehidupan sehari-hari bahkan menjadikan musik sebagai sebuah bahan pengajaran dan syiar Islam.

\begin{tabular}{ccr}
\multicolumn{2}{c}{ Perdebatan-perdebatan } & tersebut \\
kemudian & berdampak & pada \\
keberlangsungan & sistem & lembaga
\end{tabular} pendidikan yang berbasis keagamaan. Salah satunya adalah pesantren. Dhofier (1994) berpendapat pesantren merupakan lembaga pendidikan tradisional Islam untuk mempelajari dan memahami ajaran Islam sebagai pedoman perilaku kehidupan sehari-hari. Secara umum pondok pesantren dapat dikategorikan menjadi dua, yaitu pesantren salafiyah (tradisional) dan khalafiyah (modern). Pesantren yang terbagi menjadi dua jenis tersebut menunjukkan sebuah perbedaan yang mencolok. Majid (1997) mengemukakan bahwa pesantren tradisional hanya melingkupi pengajaran ilmu nahwu (struktur kalimat bahasa Arab), saraf (pembentukkan kata bahasa Arab), fiqh (hukum dan peraturan agama), a'qaid

\footnotetext{
${ }^{1}$ Terdapat perbedaan antara istilah salafiy yang menunjukkan ideologi kelompok dalam memandang hukum syariat, figh Islam dan istilah kategori salafiy tradisional dalam konteks kategori pesantren.

${ }^{2}$ Thasawuf dan thariqat merupakan cabang ilmu agama Islam dan bid'ah merupakan istilah ajaran yang tidak diajarkan nabi.
}

(akidah agama Islam), tafsir (ilmu menafsirkan Qur'an), hadis (ilmu mendalami hadis dan riwayat Nabi), bahasa Arab. Sedangkan pesantren modern sudah memasukkan berbagai disiplin ilmu yang baru termasuk musik.

Musik sebagai disiplin ilmu yang berasal dari luar wilayah ilmu Islam tradisional, mulai masuk ketika era modernisasi pendidikan di Indonesia pada awal abad 19 (Majid, 1997). Pesantren Gontor merupakan pesantren pertama pada tahun $1926^{3}$ yang memasukkan muatan pelajaran berbasis kebudayaan seperti musik, serta olah raga. Gontor sebagai pesantren yang memulai modernisasi lembaga pesantren menjadi model lembaga pendidikan yang memperbolehkan musik dalam kehidupan dan pendidikan Islam sekarang.

Mengacu pada fakta Pesantren Gontor pada paragraf sebelumnya, musik dalam pendidikan Islam atau pesantren terpengaruh oleh pandangan kelompok ulama yang membolehkan bermain dan belajar musik. Musik yang menjadi ciri Pesantren Gontor, menjadikan pesantren tersebut masuk kepada kategori modern. Menurut pemahaman yang diajukan Eagleton (1991), ideologi merupakan karakteristik ide sebuah kelompok atau kelas tertentu. Dengan demikian, dapat diargumentasikan bahwa sebuah pesantren yang melibatkan musik dalam kehidupan pembelajaran merupakan manifestasi ideologi dari kelompok ulama yang membolehkan belajar dan bermain musik.

Pesantren menjadi tempat penyebaran ideologi ulama terhadap santri ${ }^{4}$.Ulama bekerja dengan mengonstruksi pendidikan di dalam pesantren sesuai dengan ideologi mereka. Althusser (2008) menyatakan bahwa lembaga pendidikan merupakan bagian dari ISA (ideologicalstatesapparatuses) yang menyebarkan ideologi tertentu.

\footnotetext{
${ }^{3}$ Lihat pengantar Bilik-Bilik Pesantren: sebuah potret perjalanan Nurcholis Majid.

${ }^{4}$ Santri adalah istilah untuk pelajar di pesantren
} 
Pemerintah membentuk ISA dengan tujuan agar kekuasaannya bertahan. Sekolah yang didirikan oleh pemerintah pasti memiliki ideologi yang sama dengan pemerintahan. Fungsi sekolah sebagai lembaga pendidikan berusaha agar mendidik masyarakat sesuai dengan harapan dan aturan pemerintah. Ideologi negara secara persuasif disampaikan kepada masyarakat melalui sekolah. Artikel ini akan meminjam cara kerja negara dalam menyebarkan ideologinya dengan menggunakan ISA. Posisi kelompok ulama yang mempunyai otoritas dalam menentukan sebuah ideologi sama seperti sebuah negara dan pesantren sebagai lembaga pendidikan dapat disejajarkan dengan sekolah negara sebagai ISA. Proses sosialisasi ideologi ulama dilakukan secara persuasif dalam pesantren.

Barker (2004) juga mendefinisikan ideologi mengacu kepada sebuah usaha dalam memaknai sesuatu untuk melanggengkan kuasa kelompok sosial, kelas, etnis tertentu. Maka dapat disimpulkan bahwa pesantren merupakan tempat menyebarkan dan melanggengkan ideologi para ulama, dalam konteks penelitian ini ideologi tersebut adalah isu mengenai membolehkan bermain dan belajar musik di pesantren.

Kenyataan perdebatan mengenai musik dalam Islam khususnya di dunia pesantren ditampilkan dalam film berjudul Baik-Baik Sayang. Film ini menceritakan kesuksesan salah satu grup musik bernama Wali. Band Wali merupakan band yang dibentuk oleh para santri atau pelajar di pesantren La Tansa. Siregar (2011) mengemukakan bahwa film ini merupakan salah satu cara Band Wali untuk mempromosikan musik mereka. Momentum keberhasilan lagu Baik-Baik Sayang menjadi alasan untuk menjadikan judul film yang sama. Hal tersebut sejalan dengan pernyataan wawancara Band Wali yang dikutip dari laman web resmi Nagaswara (2010), bahwa kesuksesan lagu Baik-Baik Sayang sebagai RBT terlaris merupakan bukti bahwa Band Wali sudah dikenal. Selain itu, menurut Siregar (2011) film ini juga memasukkan latar belakang pendidikan pesantren yaitu La Tansa untuk menarik pasar Indonesia yang mayoritas beragama Islam.

La Tansa yang ditampilkan dalam film merupakan pesantren yang terletak di Parakansari Banten. Didirikan tahun 1991 oleh Drs. K.H Ahmad Rifai seorang ulama yang dari kecil mengenyam pendidikan pesantren di DaaruAs-salam atau Gontor. Latar belakang pendidikan Islam dan organisasi Ahmad Rifa'i menjadi pengaruh yang kuat bagi ideologi pendidikan di pesantren yang didirikannya ${ }^{5}$. Kenyataan bahwa pendiri La Tansa pernah belajar di Pesantren Gontor, serta pengaruh Gontor terhadap Ahmad Rifa'i merupakan salah satu fenomena penyebaran ideologi. Pengaruh pendidikan Gontor yang melekat pada Ahmad Rifa'i dituangkan ke dalam peraturan serta pendidikan di La Tansa. Peraturan tersebut merupakan eksistensi material dari sebuah ideologi. Argumentasi tersebut sejalan dengan pandangan Althuser yang dikutip Durham dan Kellner (2001) bahwa ideologi merupakan representasi dari hubungan imajiner antara individu dengan kondisi nyata mereka. Ideologi juga tidak hanya mempunyai eksistensi spiritual tapi juga ada dalam bentuk material. Bentuk material dari ideologi dapat dilihat dari peraturan, faham atau ide yang sudah ditubuhi oleh seseorang dan dianggap alamiah.

Hall (1995) berpendapat bahwa ideologicalstatement dibuat oleh individu. Ideologicalstatement yang dijelaskan Stuart Hall dalam essainya dapat dimaknai sebagai ekspresi individu sebagai subjek ideologi.Namun, ideologi bukan merupakan hasil dari kesadaran atau keinginan subjek ideologi secara individu. Argumentasi ini menunjukkan bahwa ekspresi seseorang merupakan manifestasi dari ideologi yang sudah ditubuhinya.

\footnotetext{
${ }^{5}$ Informasi mengenai La Tansadiperoleh dari lamanweb resmi https://latansa.sch.id/sejarahla-tansa/ dan https://latansa.sch.id/pendiripesantren/
} 
Keputusan Ahmad Rifa'i dalam memperbolehkan pendidikan musik di Pesantren La Tansa merupakan ideologicalstatement yang dihasilkan dari pengalaman pendidikannya di Gontor. Althusser (2008) juga mengemukakan bahwa setiap individu berperan dalam menyebarkan ideologi dan menjadikan masyarakatnya tunduk pada ideologi tertentu yang muncul dalam mitos, agama, dan interaksi sosial.Ideologi bekerja dengan cara menginterpelasi atau memanggil individu menjadi subjek ideologi yang terpanggil, yang merealisasikan ideologi dalam kesehariannya. Dengan terpanggilnya individu oleh ideologi, semua sendi kehidupan menjadi terpengaruh oleh ideologi tersebut dan individu tersebut berusaha mewujudkan dan mengikuti apa yang diinginkan ideologi tersebut.

Penjelasan mengenai ideologi dan cara ideologi bekerja yang sudah dijelaskan pada paragraf sebelumnya merupakan sudut pandang yang dipakai artikel ini dalam memandang legalitas musik sebagai sebuah ideologi di pesantren. Bila diperhatikan lagi, kenyataan Gontor sebagai pesantren pertama yang melegalkan musik, serta Ahmad Rifa'i sebagai alumni Gontor sekaligus pendiri Pesantren La Tansa merupakan fenomena subjek ideologi. Lebih spesifik lagi, keberadaan Band Wali sebagai alumni Pesantren La Tansa merupakan subjek ideologi yang sudah terinterpelasi.

Band Wali yang merupakan subjek ideologi dari La Tansa direpresentasikan dalam film, yang dibahas dalam artikel ini. Hall (2003) mengemukakan bahwa istilah representasi secara umum memiliki dua arti yaitu untuk menghadirkan kembali "torepresent", menggambarkan "todepict" segala sesuatu yang sebenarnya sudah ada melalui media masa baik media cetak, televisi, radio. Dalam membahas hal yang sama,Barker (2004) menegaskan juga bahwa konsep representasi biasanya merefleksikan sebuah kenyataan yang tidak murni, melainkan dipengaruhi oleh konstruksi sosial. Representasi juga selalu identik dengan isu kekuasaan.

Film sebagai sebuah media dalam menyebarkan ideologi akan merepresentasikan kembali kenyatan yang sudah terdistorsi oleh kekuasaan maupun pengaruh kelompok tertentu. Setiawan yang dikutip oleh Budiman (2018) menyebutkan bahwa narasi film memiliki potensi untuk membentuk wacana maupun ideologi dominan yang berkaitan erat dengan kepentingan kelompok tertentu. Kepentingan dan ideologi dominan dalam artikel ini adalah kepentingan ideologi kelompok yang melegalkan musik dalam pesantren.

Berdasarkan argumentasi dan pandangan serta konsep-konsep yang sudah dijelaskan, artikel ini membahas bagaimana musik sebagai sebuah ideologi serta Band Wali dan La Tansa sebagai subjek ideologi direpresentasikan dalam film Baik-Baik Sayang.

\section{B. METODE PENELITIAN}

Untuk membahas film Baik-Baik Sayang pendekatan yang digunakan adalah kajian film (film studies) yang ditawarkan oleh Amy Villarejo dan Himawan Pratista.Villarejo (2006) memandang bahwa film merupakan sesuatu yang terstruktur seperti sebuah bahasa. Film dibentuk dari unit-unit yang fundamental yang disebut shots $^{6}$ lalu digabungkan melalui proses editing menjadi sequensce ${ }^{7}$. Proses pembentukan film tersebut sama dengan pembentukan kata yang digabungkan menjadi sebuah kalimat dan kalimat menjadi sebuah paragraf. Satuansatuan kecil dalam film yang digabungkan

\footnotetext{
${ }^{6}$ Shots merupakan satuan film yang terekspose dan belum melalui proses editing lihat glosssarium dalam Vilarejo (2006).

${ }^{7}$ Sequence merupakan rangkaian shot yang dijadikan satu dalam ruang dan waktu melalui proses editing lihat glossarium dalam Villarejo (2006)
} 
akan menghasilkan sebuah gambaran utuh atau cerita.

Mengacu kepada penjelasan Hall (2003), representasi bekerja menggunakan bahasa untuk mengatakan sesuatu yang bermakna atau untuk menghadirkan kembali segala sesuatu yang memiliki arti kepada orang lain. Representasi juga menurut Gillesdan Middleton yang dikutip oleh Poyk dan Pandjaitan (2016) merupakan praktik kunci dalam produksi sebuah makna (meaning). Lebih khusus lagi representasi dapat berarti memproduksi dan bertukar makna antara anggota sebuah kebudayaan. Hammer dan Kellner (2009) juga menyatakan bahwa teori representasi menekankan bagaimana proses representasi terjadi dan bagaimana makna representasi tersebut dibentuk terutama di media masa. Representasi juga merupakan kaitan yang erat produksi makna media masa dengan kekuasaan dan ideologi. Berdasarkan pandangan mengenai representasi tersebut dapat diargumentasikan bahwa representasi yang berkaitan dengan film sebagai media, dibentuk menggunakan bahasa film. Bahasa film yang dimaksud adalah struktur dan teknik narasi dalam film.

Lebih spesifik lagi, Humpries yang dikutip oleh Villarejo (2006) menganggap bahwa kajian film adalah mempertanyakan nilai dan gagasan dalam film. Nilai dan gagasan dalam film didapatkan setelah memahami unsur-unsur dalam film tersebut.Villarejo (2006) berpendapat bahwa untuk memahami unsur-unsur dalam film, kita harus faham bagaimana segala sesuatu yang membentuk film ditampilkan atau disebut mise-enscene.

Selain dari mise-enscene, hal lainnya yang penting dalam menganalisis film adalah sinematografi. Villarejo (2006) mengartikan sinematografi sebagai segala sesuatu yang berhubungan dengan kamera. Apabila mise-enscene berkaitan dengan unsur pembentuk film, cinematography berkaitan dengan bagaimana kamera menangkap segala sesuatu yang akan ditampilkan dalam film.
Pada hal yang sama, menurut Pratista (2008) film setidaknya dibagi menjadi dua unsur pembentuk yaitu, unsur naratif dan unsur sinematik. Unsur naratif merupakan bahan atau materi yang akan diolah menjadi film, sedangkan unsur sinematik adalah cara untuk mengolahnya.Unsur naratif sebuah film berhubungan dengan aspek cerita dari film tersebut. Unsur naratif dalam film juga merupakan suatu rangkaian peristiwa yang saling berhubungan, terikat oleh logika serta terikat dalam ruang dan waktu.Boggs dan Petrie yang dikutip oleh Nurfaidah (2016) juga menyatakan hal yang lebih spesifik, bahwa unsur naratif dalam film dapat terdiri dari tema, alur dan penokohan. Namun, penjelasan mengenai unsur naratif dalam artikel ini akan dituangkan dalam bentuk sebuah cerita. Penjelasan cerita ini hanya difokuskan pada unsur yang mendukung representasi ideologi Pesantren La Tansa dan Band Wali. Penjelasan cerita film ini juga ditujukan sebagai materi pendukung dalam penjelasan bagian analisis.

Data yang mendukung untuk dapat menjelaskan fenomena yang terjadi dalam film juga diperoleh dari unsur sinematik. Pratista (2008) mengemukakan bahwa unsur sinematik lebih menekankan kepada teknik pengambilan gambar seperti framing, dan shot. Unsur sinematik merupakan unsur penting dalam film yang mendukung unsur naratif dalam menggambarkan cerita dan detail dari film.

\section{HASIL DAN BAHASAN \\ 1. Representasi La Tansa, Band Wali dan Musik}

Film Baik-Baik Sayang merupakan film karya Somad Sutedja yang bergenre drama biografi. Pratista (2008) mengemukakan bahwa genre biografi merupakan film yang mengisahkan perjalanan hidup seorang tokoh terkenal sebelum dia terlibat dalam sebuah peristiwa besar, sedangkan drama adalah film yang banyak mengisahkan kisah yang menggugah emosi serta dramatik. Tokoh 
yang menjadi sentral dalam film ini adalah personel Band Wali.

Band Wali merupakan group musik yang mengusung musik pop dengan balutan tema religi sesuai dengan latar belakang pendidikan mereka yang berasal dari Pesantren La Tansa. Band ini terdiri dari Fa'ank vokalis, Apoy gitaris, Tomidrumer dan Ovie pianis. Kesuksesan Band Wali digambarkan dalam film ini bermula dari pertemuan awal para personel band di Pesantren La Tansa.

Adalah vokalis $\mathrm{Fa}$ 'ank yang paling banyak diceritakan dalam film. Fa'ank menjadi tokoh protagonis yang menulis salah satu lagu Band Wali paling terkenal berjudul Baik-Baik Sayang. Judul film ini pun diambil dari judul lagu yang sama. Hal tersebut dikarenakan tema utama dari film ini menceritakan kesuksesan Band Wali melalui lagunya tersebut.

Fa'ank diceritakan berasal dari keluarga sederhana yang jauh dari kedekatan dunia musik. Kedua orang tuanya yang berlatar belakang muslim fanatik terlihat dari penggambaran beberapa adegan dalam film yang melarang Fa'ank terlibat dalam dunia musik seperti menonton konser musik. Namun, kecintaan Fa'ank terhadap musik membuat dia melakukan perlawanan dengan cara membohongi kedua orang tuanya.

Kebohongan yang dilakukan Fa'ank demi kecintaannya terhadap salah satu band yang juga terkenal saat itu yaitu Kangen Band, berhasil membuat Fa'ank menonton konser mereka. Namun, kebohongan Fa'ank berbuah kesialan. Fa'ank mengalami kecelakaan sepulang dari menonton konser. Orang tua Fa'ank merasa marah dan kecewa terhadap kelakuan Fa'ank. Kedua orang tua Fa'ank memutuskan untuk memindahkan sekolah Fa'ank ke Pesantren La Tansa dengan harapan Fa'ank akan menjauh dari dunia musik dan menjadi santri yang soleh.

Satu hal yang menarik dari bagian film ini adalah adanya pandangan yang berasal dari salah satu kelompok ulama
Islam yang melarang musik dalam kehidupan. Pandangan tersebut dituangkan menjadi latar belakang pengetahuan kedua orang tua Fa'ank. Adegan Ayah Fa'ank memutuskan untuk memindahkan sekolah dilakukan dengan teknik penggambilan gambar atau framing. Pratista (2008) menjelaskan bahwa framing merupakan pembatasan gambar oleh kamera dengan tujuan menjelaskan objek secara detail atau menggambarkan emosi karakter secara detail. Ideologi melarang memainkan dan mendengarkan musik yang terdapat dalam ayah Fa'ank tergambar jelas dalam ekspresi wajahnya melalui tekni0k framing tersebut. Selain dari ekpresi yang diperjelas teknik framing, keberadaan ideologi melarang memainkan dan mendengarkan musik juga dapat dilihat dalam kutipan dialog antara Fa'nk dan ayahnya berikut ini:

Fa'ank : pesantren $B i^{8}$ ?

Ayah :iya pesantren!, kenapa?, Kaти jangan mengecilkan hati pesantren.Fa'ank, Fa'ank, hei, lihat Abi, lihat Abi. Beberapa teman Abi anaknya disekolahkan di pesantren. Jadi Abi tahu jelas kalau pesantren ini sekolah yang bagus. Para santri digembleng untuk menjadi manusia yang berdisiplin tinggi, berkualitas dan yang pasti kamu nggak bisa lagi bermain gitar, bernyanyinyanyi yang nggak jelas. Ngerti kamu?

Fa'ank : iya Bi, iya”

Adegan dan dialog antara ayah Fa'ank dan Fa'ank dapat dibaca sebagai representasi ideologi kelompok ulama yang melarang memainkan dan mendengarkan musik. Ayah Fa'ank sudah memiliki ideologi bahwa pesantren merupakan tempat di mana anaknya tidak akan bermain musik. Ideologi ini

\footnotetext{
${ }^{8}$ Abi merupakan panggilan ayah dalam bahasa Arab
} 
ditunjukkan dengan kalimat yang terdapat dalam dialog: “...dan yang pasti kamu tidak bisa lagi bermain gitar, bernyanyinyanyi yang nggak jelas". teknik framing yang menunjukkan wajah ayah Fa'ank ditampilkan bersamaan dengan dialog tersebut. Wajah ayah Fa'ank juga diambil dengan menggunakan sudut kamera closeup. Gabungan teknik narasi dan teknik film tersebut mengajak penonton melihat dengan jelas apa yang akan disampaikan oleh ayah Fa'ank. Lebih khususnya lagi adegan tersebut memberikan penekanan bahwa apa yang diucapkan oleh ayah Fa'ank merupakan hal yang disengaja dan disadari, sehingga penonton dapat melihat posisi ayah $\mathrm{Fa}^{\prime}$ ank terhadap anaknya.

Posisi ayah Fa'ank
direpresentasikan oposisi secara ideologis terhadap kegiatan bermusik Fa'ank. Namun, ayah Fa'ank tidak mengetahui bahwa Pesantren La Tansa memiliki ideologi yang membolehkan memainkan dan mendengarkan musik. Urutan unsur naratif tersebut direpresentasikan dalam film agar mengajak penonton membandingkan antara ideologi yang dimiliki ayah Fa'ank dengan La Tansa.

Ideologi mengenai kelompok ulama yang melarang mendengarkan dan memainkan musik juga terdapat di adegan lain yakni adegan ketika Fa'ank dan para personel lainnya terpaksa harus membersihkan toilet. Salah satu teman sekamar mereka Hamzah yang menjadi tokoh antagonis melaporkan kesalahan Fa'ank dan kawan-kawan. Dalam adegan tersebut Hamzah ditegur oleh Apoy seperti terdapat dalam kutipan percakapan berikut ini:

$$
\begin{array}{cl}
\text { Apoy } \quad \text { : Zah!! limaatukridzina Lay } \\
\text { naa? } \\
\text { (kenapa kamu benci kepada } \\
\text { kita? })^{9} \\
\text { Hamzah } \\
\begin{array}{c}
\text { al-ginnaharaam, al Gina } \\
\text { yud'aifuul-iman }
\end{array}
\end{array}
$$

\footnotetext{
${ }^{9}$ Terjemahan dan transliterasi dari bahasa Arab
} oleh DzulfikarAl-anbiya. (musik itu haram, musik melemahkan iman)

Sosok Hamzah disorot dengan tehnik framing medium shot yang bertujuan meperlihatkan gestur dan raut wajah Hamzah yang menolak musik dalam kehidupannya. Lebih spesifik lagi, unsur naratif film memosisikan Hamzah sebagai tokoh antagonis utama. Hal tersebut menarik, karena selain sebagai musuh dari para personel Band Wali, Hamzah juga direpresentasikan memiliki ideologi yang melarang memainkan dan mendengarkan musik. Ideologi tersebut semakin jelas ketika Hamzah menyebutkan musik itu haram.

Hamzah sebagai tokoh antagonis utama dalam film, juga menjadi representasi ideologi kelompok ulama yang melarang memainkan dan mendengarkan musik. Dilekatkannya ideologi tersebut dalam tokoh Hamzah menjadikan konflik antara tokoh protagonis dan antagonis ideologis. Hubungan yang terjadi antara tokoh protagonis dan antagonis dapat diargumentasikan merupakan representasi dari perdebatan ideologi antara subjek ideologi kelompok ulama yangmelarang memainkan dan mendengarkan musik dengan yang membolehkan musik.

Larangan memainkan dan mendengarkan musik sebagai hal yang ideologis berkelindan dengan konflik yang terjadi antara antagonis dan protagonis. Setiap detail konflik di antara mereka selalu berkaitan dengan ideologi tersebut. Teknik kameracmenampilkan detail konflik perbedaan ideologi tersebut. Adapun dialog antara Hamzah dan personel Band Wali ditampilkan dengan teknik kamera berbeda. Dialog yang dilakukan Hamzah menggunakan medium shot, sehingga secara kuantitas hanya menampilkan seseorang. Sedangkan dialog yang dilakukan Apoy menggunakan medium longshot, sehingga jumlah personel yang terbawa oleh shot untuk Apoy lebih banyak. Hal tersebut menunjukkan bahwa ideologi Band Wali 
lebih dominan dibandingkan dengan ideologi Hamzah. Dominasi tersebut juga dapat terlihat lebih jelas dengan menyoroti La Tansas ebagai latar terjadinya adegan tersebut.

La Tansa direpresentasikan sesuai kenyataan aslinya. Semua latar yang diambil merupakan lokasi sebenarnya dari Pesantren La Tansa. Detail dari pesantren tersebut tidak dirubah ataupun disamarkan. Simbol pesantren dan gapura pintu gerbang luar La Tansa ditampilkan dengan gerakan kameratilt-up, sehingga dapat terlihat situasi dan keadaan pesantren yang luas dan megah. Teknik tilt-up juga memberikan keyakinan bahwa segala unsur naratif yang ditampilkan dalam film berada di La Tansa. Selain itu, (Pratista (2008)) mengemukakan bahwa penggunaan latar yang sesuai dengan kenyataan atau shot on location bertujuan untuk memberi efek nyata dan membantu unsur naratif dalam film. Shot on location juga meyakinkan penonton bahwa $L a$ Tansa merupakan pendukung utama Band Wali menjadi terkenal. Argumentasi tersebut sesuai dengan kenyataan bahwa terdapat ekstrakurikuler dan pengajaran musik yang menjadi wadah para personel Band Wali bermusik.

La Tansa sebagai instansi pendidikan yang membolehkan memainkan dan mendengarkan musik digambarkan juga dalam film dengan menayangkan adegan marchingband. Adegan tersebut diambil dengan tehnik framing medium shot dalam durasi shotlongtake yang bertujuan untuk memperlihatkan kondisi marchingband dan menekankan detail bahwa marchingband santri diikuti oleh santri baik lelaki dan perempuan serta menonjolkan jumlah santri pengikut marchingband yang banyak.

Representasi La Tansa sebagai instansi yang membolehkan musik tidak hanya dengan memunculkan kegiatan marchingband. Film ini bahkan menunjukkan secara eksplisit bahwa Pesantren La Tansa mendukung penuh serta bertanggung jawab terhadap kegiatan bermusik di lingkungan pesantrennya melalui adegan pemberitaan acara televisi. Adegan ini menggunakan framing medium longshot untuk memperjelas dan memperlihatkan latar adegan. Latar digambarkan seperti studio acara televisi (gambar 1). Pembawa acara dalam adegan ini membacakan berita yang secara eksplisit menyebutkan musik sebagai ciri khas La Tansa: "pemirsa...keunikan dari pesantren ini adalah apresiasinya yang begitu tinggi terhadap dunia kesenian populer. Selain kegiatan marawis yang memang ada di pesantren-pesantren, La Tansa juga memiliki kegiatan ekstrakurikuler drumband. Nah...ini dia uniknya, grup band juga ada dan biasa menyanyikan lagu-lagu populer".

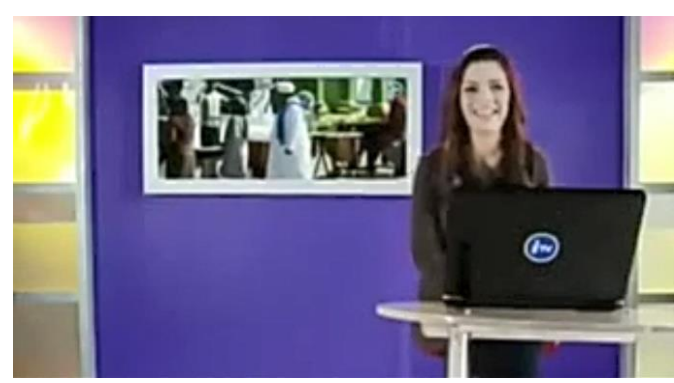

Gambar 1. La Tansa Diberitakan dalam Acara Televisi Sumber:

https://m.youtube.com/watch? $v=9 K T L q c 15 d 8 w$

Selanjutnya mudir melakukan wawancara dengan presenter. Teknik kamera adegan ini menggunakan point of viewshot. Kamera memandang sama persis dengan apa yang dipandang tokoh dalam film. Salah satu tokoh dalam adegan sedang menonton acara televisi tersebut. Teknik ini digunakan agar kita bisa merasakan sensasi dan sudut pandang tokoh dalam adegan. Dalam adegan ini mudir memberikan pernyataan jelas mengenai posisi La Tansa yang mendukung kegiatan bermusik: "dakwah itu bisa dilakukan dengan cara apa saja dan dalam bentuk apa saja, selain juga dengan berdakwah yang cara konvensional. Termasuk juga lewat 
bernyanyi, dan kalau ada grup band yang penggemarnya ribuan, kenapa kita tidak coba berdakwah melalui hal itu".

Dalam acara interview itu juga ditunjukkan para santri perempuan yang melakukan aktivitas bermain musik marawis. Adegan para santri tersebut daimbil seolah-olah berada dalam acara tv dengan menampilkan watermark atau logo dari televisi tersebut. Film ini juga merepresentasikan bahwa Pesantren $L a$ Tansa memang benar-benar pesantren yang mendukung pendidikan dalam bidang seni musik. Beberapa adegan dalam film 'Baik-Baik Sayang' tersebut menggambarkan bahwa Pesantren $L a$ Tansa merupakan pesantren yang plural dan terbuka terhadap kebudayaan.

Penggambaran La Tansa dalam film secara eksplisit menunjukkan ideologi kelompok ulama yang membolehkan musik. La Tansa direpresentasikan menggunakan teknik-teknik kamera yang menonjolkan sisi keunggulannya. Point of view shot adegan wawancara mudir dapat dibaca sebagai pesan bahwa La Tansa sudah banyak berpengaruh bagi masyarakat. Adegan tersebut juga merupakan gambaran bahwa La Tansa dengan ideologinya berhasil membuat Band Wali terkenal. Argumentasi tersebut didapat jika melihat kenyataan Band Wali sebagai subjek ideologi La Tansa yang ditampilkan memecahkan rekor MURI sebagai $\mathrm{RBT}^{10}$ terlaris.

Berangkat dari semua unsur naratif dan sinematik yang ditampilkan dalam film, dapat diargumentasikan bahwa $L a$ Tansa dan Band Wali dalam film merupakan representasi dari kelompok ulama yang membolehkan memainkan dan mendegarkan musik. La Tansa sebagai ISA dan Band Wali sebagai subjek ideologinya yang juga tokoh utama direpresentasikan dalam film sebagai ideologi yang lebih ditonjolkan dan dominan.

10 RBT atau Ring Back Tone merupakan layanan nada sambung pada telepon selular

\section{Representasi Bentuk Ideologi yang berbeda dalam Sosok Hamzah dan Ayah Fa'ank}

Tokoh dalam film yang akan dibahas pada bagian ini merupakan lawan dari ideologi yang dimiliki La Tansa dan Band Wali. Adalah Hamzah dan ayah Fa'ank yang direpresentasikan memiliki ideologi kelompok ulama yang melarang memainkan dan mendengarkan musik. Kedua tokoh ini baik secara unsur naratif maupun sinematik semua menunjukkan ideologi tersebut.

Hamzah tokoh antagonis dalam film yang menunjukkan ideologi berlawanan dengan La Tansa dan Band Wali. Hamzah digambarkan sebagai sosok yang iri dan dengki terhadap para personel Band Wali. Argumentasi tersebut dapat terlihat sejak awal film. Bagian awal film diceritakan $\mathrm{Fa}$ 'ank mengigau dan menjadi bahan lawakan personel band lainnya. Latar adegan ini berada di dalam asrama. Kejadian tersebut disaksikan oleh Hamzah yang terbangun karena kegaduhan para personel Band Wali. Pada adegan ini Hamzah memperlihatkan ekspresi sinis dan kesal karena terganggu tidurnya. Kamera menampilkan wajah Hamzah menggunakan teknik framing dan jarak shot closeup. Wajah Hamzah menjadi fokus utama adegan tersebut. Ekspresi Hamzah akan menjadi fokus penonton sehingga akan terlihat bahwa Hamzah diposisikan sebagai antagonis.

Selanjutnya adegan yang menjadi bukti bahwa Hamzah tokoh antagonis adalah adegan dihukumnya semua personel Band Wali oleh mudir. Hamzah yang pada adegan sebelumnya terganggu tidurnya oleh kegaduhan para personel Band Wali ternyata melaporkan kejadian tersebut. Hamzah melaporkan bahwa para personel Band Wali berbicara menggunakan bahasa Indonesia di dalam lingkungan La Tansa.

Hamzah juga direpresentasikan sebagai musuh bebuyutan para personel Band Wali. Adegan para personel Band Wali sedang menjalani hukuman menjadi 
dasar argumentasi tersebut. Hamzah menjadi bahan pergunjingan para personel Band Wali. Perbincangan tersebut selalu menggunakan bahasa Indonesia. namun ketika Hamzah lewat mereka segera menggunakan bahasa Arab karena mengetahui bahwa Hamzah akan mengadukan mereka. Hamzah juga bahkan sampai mencederai Apoy ketika melakukan ekstrkurikuler pencak silat.

Adegan yang dibahas pada beberapa paragraf sebelumnya menunjukkan bukti bahwa Hamzah dalam film diposisikan sebagai sosok antagonis. Pentingnya posisi Hamzah sebagai sosok antagonis berhubungan dengan representasi ideologi kelompok ulama yang melarang memainkan dan mendengarkan musik. Musik yang direpresentasikan sebagai sebuah hal yang ideologis di pesantren menjadi sudut pandang artikel ini. Hamzah yang memiliki konflik dengan personel Band Wali dapat dibaca lebih mendalam. Selain konflik antara protagonis dan antagonis, hubungan Hamzah dan personel Band Wali merupakan konflik yang ideologis. Sepeti yang sudah dijelaskan pada bagian pertama, bahwa setiap konflik tokoh utama dengan antagonis berkelindan dengan konflik ideologis mereka.

Konflik ideologis antara Hamzah dan Band Wali terlihat dari cara kamera menampilkan kedua tokoh yang berbeda. Hamzah sebagai antagonis mendapatkan teknik kamera yang kurang berpihak terhadapnya. Konflik yang ditampilkan film selalu lebih berpihak kepada La Tansa dan Band Wali sebagai ideologi yang ditonjolkan oleh film. Hal tersebut dapat dilihat dari setiap unsur sinematik dan naratif yang berhubungan dengan konflik yang terjadi di antara mereka. Sebagai antagonis, Hamzah selalu melakukan perbuatan yang menghalangi dan mengganggu Band Wali. Namun, teknik kamera dan unsur-unsur naratif selalu dikondisikan memihak para pemeran utama. Seperti pada film bergenre drama yang umum, akhir cerita selalu berakhir bahagia untuk protagonis. Unsur naratif tersebut berpihak pada Band Wali sebagai protagonis dan juga sebagai subjek ideologi La Tansa. semua perbuatan Band Wali sebagai representasi dari idelogi kelompok yang membolehkan musik akan bedampak pada Hamzah sebagai antagonis dan representasi subjek ideologi lawan.

Hamzah sebagai representasi ideologi yang berbeda dapat kita buktikan dengan beberapa adegan. Penelusuran bukti tetrsebut terlihat dari adegan penolakan Hamzah terhadap ajakan Band Wali untuk latihan band bersama. Apoy melihat Hamzah berjalan melewati mereka dan memanggilnya :

\section{Apoy : Zah! satatamaaran And ma'anaa? \\ ( Zah ! kamu mau latihan band bareng kita?) \\ Hamzah : Na'udzubillahi min dzaalika! \\ Harram! \\ ( aku berlindung kepada Tuhan dari hal tersebut! ${ }^{11}$ haram!)}

Hamzah menolak ajakan Band Wali. Penolakan tersebut merupakan bentuk konflik ideologis. Hamzah menyebutkan bahwa musik itu haram. Lebih spesifik lagi, urutan naratif adegan tersebut ada setelah adegan konflik Hamzah dan Band Wali yang sudah dijelaskan pada bagian pertama. Ajakan Band Wali dapat dikatakan seperti ejekan untuk Hamzah, pasalnya mereka sudah mengetahui bahwa Hamzah memiliki ideologi yang melarang memainkan dan mendengarkan musik.

Unsur sinematik pada adegan tersebut juga lebih memihak personel Band Wali dibandingkan posisi Hamzah. Band Wali selalu ditampilkan menggunakan teknik medium longshot. Jumlah tokoh yang tertangkap kamera oleh teknik tersebut lebih banyak, serta latar yang ditampilkan juga ikut terbawa. Sedangkan sosok

\footnotetext{
11 Kalimat ini merupakan terjemahan literal dari bahasa Arabnya. Namun, kalimat tersebut digunakan untuk menunjukkan ekspresi penolakan
} 
Hamzah kembali ditampilkan Perbedaan penggunaan teknik tersebut berakibat pada seberapa banyak dominasi setiap ideologi. Band Wali yang selalu ditampilkan kompak dengan jumlah yang lebih banyak menandai jumlah subjek ideologi yang terinterpelasi lebih banyak dibandingkan dengan Hamzah yang selalu ditampilkan sendiri. Lebih spesifik lagi, ditinjau dari latar La Tansa sebagai tempat kejadian. Hamzah merupakan satu-satunya tokoh yang selalu ditampilkan mengharamkan musik di pesantren.

Adegan lain yang menunjukkan konflik ideologis antara Hamzah dan Band Wali adalah setiap Hamzah mendapat kesialan. Pada paragraf sebelumnya sudah disebutkan bahwa Hamzah pernah mencederai Apoy ketika sedang melakukan pencak silat. Sekilas adegan tersebut menunjukkan keunggulan antagonis. Namun, urutan unsur naratif lebih memihak tokoh utama. Setelah adegan tersebut, Apoy kembali ditampilkan dikelilingi sahabat-sahabatnya di ruang $\mathrm{UKS}^{12}$. Tampilan latar yang diberikan kepada Apoy berbanding terbalik ketika Hamzah diceritakan mendapatkan kesialan setelah melaporkan perkelahian antara Fa'ank dan Tomi. Hamzah, tokoh antagonis yang dicirikan sebagai seorang pengadu berharap personel Band Wali mendapatkan hukuman dari guru. Namun, para personel Band Wali serta para santri yang lainnya sepakat untuk menutupi kejadian tersebut, sehingga Hamzah mendapatkan teguran dari gurunya karena tidak dapat membuktikan laporannya. Hamzah ditampilkan dengan ekspresi ketakutan karena melihat sang guru marah terhadapnya. Kamera menggunakan teknik closeupuntuk memperjelas ekspresi wajah hamzah yang takut. Selain itu, teknik kamera medium shot dengan gerakan tiltdown digunakan untuk menyoroti bagian kaki Hamzah. Kamera bergerak

\footnotetext{
${ }^{12}$ UKS unit kesehatan siswa atau ruangan perawat sekolah.
}

dari bagian pinggul hingga tumit untuk menangkap detail celana Hamzah yang basah terkena air seni. Tiltdownserta kombinasi lowangle juga mempertegas perawakan Hamzah yang besar (gambar 2). Unsur sinematik, yang diberikan pada adegan tersebut bertujuan agar sosok Hamzah menjadi lucu.

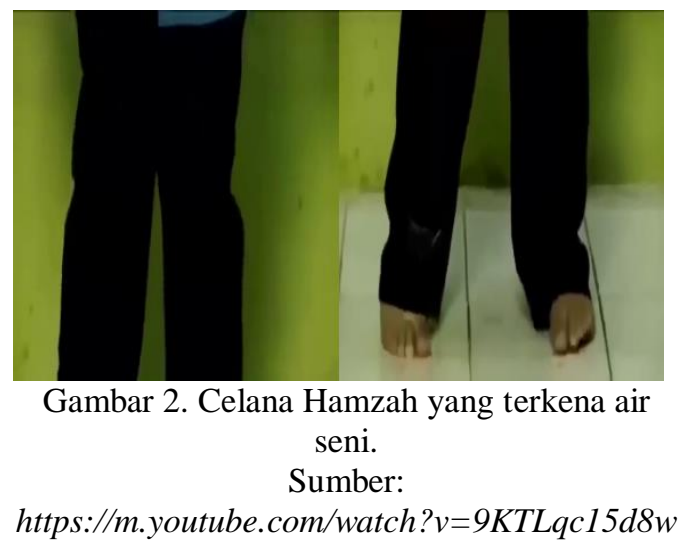

Kesialan yang menimpa Hamzah merupakan unsur naratif dan sinematik yang dibuat membedakan tokoh antagonis. Latar adegan Hamzah dimarahi oleh guru juga ditampilkan lebih memihak terhadap Band Wali. Hamzah berada pada posisi yang dikerumuni oleh guru yang merupakan representasi dari La Tansa, sedangkanBand Wali berada pada posisi bersama dengan teman-teman satu asrama yang lain. Setelah Hamzah dimarahi dan ditampilkan menggunakan unsur sinematik yang sedemikian rupa, Hamzah dijadikan bahan lelucon semua penghuni asrama dan anggota Band Wali. Hamzah terlihat direpresentasikan sebagai sosok antagonis yang ideologinya berbeda. Kebencian Hamzah terhadap ideologi memainkan dan mendengar musik dalam Band Wali terlihat menjadi hal yang lebih mencolok perbedaannya.

Adegan lain yang menggambarkan Hamzah menjadi bahan lelucon dan sosok yang berbeda adalah ketika liburan semester tiba. Semua santri pulang ke rumah masing-masing dan berpamitan kepada mudir. Semua santri termasuk Band Wali ditampilkan berkerumun bersama-sama. Ekspresi bahagia 
ditampilkan pada wajah para santri karena mereka dijemput oleh orang tua masingmasing. Namun, Hamzah tidak dijemput oleh orang tua melainkan oleh ajudan ayahnya. Hamzah terpaksa harus naik mobil pick-up yang berisikan kambing dikarenakan mobil yang menjemputnya mogok. Semua santri yang melihat kejadian tersebut tertawa terbahak-bahak. Terlebih lagi, sosok ajudannya diperankan oleh Tessy. Pada adegan ini, kamera menyoroti kedua kubu dengan teknik medium longshot. Teknik tersebut memperjelas latar kedua kubu. Hamzah ditampilkan berdua dalam frame dengan sang ajudan, sedangkan Band Wali berada pada frame bersama santri yang lain. Tampilan adegan tersebut dapat dibaca sebagai posisi Hamzah yang berbeda. Posisi Hamzah tersebut juga merepresentasikan ideologi Hamzah yang berlawanan serta membedakannya dari Band Wali dan La Tansa.

Tokoh selanjutnya yang merepresentasikan ideologi berlainan adalah ayah Fa'ank. Berbeda dengan Hamzah, ayah Fa'ank bukanlah antagonis. Ayah Fa'ank dapat dikatakan hanya memiliki konflik dengan anaknya karena perbedaan ideologis. Ayah Fa'ank merupakan sosok yang digambarkan fanatik terhadap agama Islam. Argumentasi tersebut didukung oleh fakta dalam film yang selalu mengaitkan ayah Fa'ank dengan sesuatu yang berbau Islam. Ayah Fa'ank ditampilkan selalu menggunakan peci. Fanatisme ayah Fa'ank juga ditampilkan melalui nama panggilan. Fa'ank selalu memanggil ayah dan ibunya dengan panggilan abi dan umi. Fanatisme ini juga yang menjadikan ayah Fa'ank memiliki ideologi yang berbeda dari Fa'ank, Band Wali dan La Tansa. seperti yang sudah dijelaskan pada bagian pertama, ayah Fa'ank berideologi melarang memainkan dan mendengarkan musik.

Konflik ideologis pertama ayah Fa'ank ditunjukkan pada adegan kunjungan ke pesantren. Fa'ank seharusnya menerima kunjungan dari kedua orang tuanya. Namun, Fa'ank didatangi oleh ibunya. Ayah Fa'ank tidak dapat hadir karena harus mengunjungi kakak Fa'ank yang seorang taruna di Akademi Militer. Fa'ank menunjukkan kekecawaannya dengan sindiran yang terdapat pada percakapan dengan ibunya berikut:

Ibu : Aduh, apa kabar kamu nak? Kamu sehat-sehat saja?

Fa'ank : Alhamdulilah mi,umi ke sini sama siapa mi?

Ibu : Sama ibu Tina, waduh tapi Ke mana dia ya? Fa'ank! Ternyata anaknya ada yang sekolah di sini juga, tapi kelas satu

Fa'ank : Abi mana mi?koga ikut? (raut wajah murung)

Ibu : Abi lagi ke Magelang. Kakakmu sakit!

Fa'ank :Tentara?! sakit juga? (bernada kesal)

Ibu :Fa'ank, kenapa sih kamu sinis gitu sama kakak kamu?jangan pernah berpikir kalau abi kamu pilih kasih antara kakakmu dan kamu ya! di rumah terasa sepi karena ngga ada kamu ank (sambil menghela nafas)

Fa'ank :Ajak aja abi bercanda!! abi kan lucu mi !!

Ibu : Hus! Ko gitu sih ngomongnya

Kekecewaan Fa'anktersebut menunjukkan bahwa terjadi konflik dengan ayah Fa'ank. Pada bagian pertama sudah dijelaskan bahwa penyebab Fa'ank berakhir di $L a$ Tansa adalah ayahnya. Fa'ank merasa bahwa ayahnya tidak bertanggung jawab karena tidak menjenguknya. Ayah Fa'ank lebih mengutamakan anaknya yang menjadi taruna di Akademi Militer. Konflik ideologis lebih jelas terlihat karena sebelumnya ayah Fa'ank sangat kecewa dengan anaknya yang bermain musik.

Ayah Fa'ank yang kecewa terhadap kegiatan bermusik Fa'ank juga ditampilkan pada adegan yang kedua, 
perjalanan ketika liburan semester tiba. Ayah Fa'ank terlihat lebih bangga dan bahagia dengan kakak Fa'ank yang seorang taruna. Selama perjalanan tersebut ayah Fa'ank membandingkan prestasi antara kakak dan adik. Keberpihakan ayah Fa'ank terlihat pada percakapan berikut:

Ayah : Ank! sebentar lagi kakak kamu akan dilantik menjadi letnan. Hahaha...abi bangga dengan kakak kamu. Makanya kamu harus rajin belajar. Jangan sampai kamu ketinggalan sama kakak kamu! Ya kan bu? (ekspresi wajah bahagia)

Ibu :iya..(sambil mengangguk dan menatap wajah Fa'ank)"

Ayah :yang pasti Fa'ank, jadi tentara itu punya banyak kesempatan untuk meniti karir masa depan. Iya kan bu? (wajah serius)

Ibu :(ibu menjawab dengan mengangguk)

Dalam adegan percakapan tersebut, Fa'ank digambarkan kecewa sembari dipeluk ibunya. Penyebab kekecewaan Fa'ank adalah pandangan ayah Fa'ank yang menganggap karir TNI lebih cerah. Kedua adegan percakapan tersebut menunjukkan bahwa ayah $\mathrm{Fa}$ 'ank lebih memilih karir TNI untuk Fa'ank dibandingkan musik.

Konflik ideologis selanjutnya tidak berkaitan langsung dengan Fa'ank. Namun, berkaitan dengan Pesantren $L a$ Tansa tempat Fa'ank mendapatkan dukungan bermain musik. Konflik ini terdapat pada adegan ketika ayah Fa'ank menonton acara televisi yang menampilkan interview mudir La Tansa. Ayah Fa'ank menunjukkan penolakan terhadap pandangan mudir yang mengizinkan musik ada di pesantren seperti yang terlihat pada percakapan berikut:

Ibu : Bi pondok bi! (sambil menunjuk ke arah mudir di dalam televisi)

Ayah :haaa...ngaco! yang enggak enggak aja. Masa di pesantren ada band?
Dilihat dari urutan naratifnya, adegan ini merupakan adegan ayah Fa'ank yang benar-benar menolak ideologi memainkan dan mendengarkan musik di pesantren secara jelas. Konflik ideologis ayah Fa' ank pada beberapa adegan sebelumnya tidak secara langsung memberikan penolakan kepada La Tansa sehingga dengan adanya adegan ini dan diperkuat oleh adegan sebelumnya ayah Fa'ank dapat diargumentasikan memiliki ideologi berlawanan dengan La Tansa dan Band Wali.

Fa'ank $\begin{array}{ccc}\text { Namun, konflik } & \text { ideologis } & \text { ayah } \\ \text { dalam } & \text { film } & \text { tidak }\end{array}$ merepresentasikannya sebagai antagonis layaknya Hamzah. Perbedaan ideologi ayah Fa'ank direpresentasikan lebih negosiatif terhadap ideologi memainkan dan mendengar musik. Hal tersebut dapat dilihat di beberapa adegan terakhir dalam film.

Adegan pertama yang menunjukkan posisi ayah Fa'ank yang negosiatif adalah ketika Band Wali sukses dan mendapatkan rekor MURI untuk RBT terbanyak di Indonesia. Band Wali dalam adegan ini berada dalam sebuah acara penghargaan televisi. Dalam adegan ini terdapat unsur sinematik dan unsur naratif yang menunjukkan argumentasi tersebut. Adapun posisi negosiatif ditunjukkan dalam percakapan ibu Fa'ank dan ayah Fa'ank berikut:

Ibu : Abi! Abi!Fa'ank nyanyi abi (menunjuk ke arah televisi)

Ayah :Fa'ank? (sembari berjalan dari ruangan lain ke ruang keluarga

Ibu : iya!(menunjukkan ekspresi senang

Ayah : Fa'ank.... (menunjukkan ekspresi kagum)

Ayah Fa'ank ditampilkan mulai menerima Fa'ank yang sukses dengan karir musiknya. Kamera menyoroti wajah ayah Fa'ank dengan teknik closeup sehingga detail wajah yang menunjukkan ekspresi kagum terlihat jelas. Posisi ideologi ayah 
Fa'ank ditampilkan lebih negosiatif. Pada satu sisi ayah Fa'ank menolak ideologi yang memainkan dan melarang musik, di sisi lain kagum terhadapa pencapaian Fa'ank bersama Band Wali.

Pencapaian Fa'ank yang ditampilkan dalam televisi juga diambil menggunakan teknik kamera tilt dengan jarak medium closeup. Kamera bergerak mulai dari foto kakak Fa'ank yang menggunakan seragam Akademi Militer hingga ke arah televisi yang menampilkan Band Wali di dalamnya. Teknik tersebut mengarahkan penonton agar bisa melihat bahwa pandangan ayah $\mathrm{Fa}$ 'ank mengenai TNI mempunyai keunggulan dibandingkan karir bermusik Fa'ank mengalami perubahan.

Selanjutnya, ayah Fa'ank sebagai representasi dari kelompok ideologi melarang mendengarkan dan memainkan musik ditampilkan juga lebih negosiatif pada adegan yang terakhir. Ayah Fa'ank menghadiri konser Band Wali bersama ibu Fa'ank dan teman-temannya. Adegan ini menunjukkan negosiasi yang dilakukan ayah Fa'ank. Pada adegan-adegan sebelumnnya ayah Fa'ank ditunjukkan menolak ideologi $L a$ Tansa yang membolehkan mendengar dan memainkan musik.

Melalui penjelasan representasi tokoh Hamzah dan ayah Fa'ank, dapat disimpulkan bahwa kedua tokoh ditampilkan sebagai pembanding ideologi La Tansa dan Band Wali yang dominan. Hamzah sebagai tokoh antagonis yang merepresentasikan kelompok yang melarang mendengar dan memainkan musik ditampilkan sebagai lawan utama. Ayah Fa'ank yang menolak ideologi mendengar dan memainkan musik ditampilkan berada di antara La Tansa dan Hamzah atau negosiatif.

\section{PENUTUP}

Film

Baik-Baik Sayang merepresentasikan musik di pesantren sebagai hal yang ideologis. Pandangan membolehkan mendengar dan bermain musik merupakan ideologi yang paling ditonjolkan dalam film. La Tansa sebagai instansi yang menaungi Band Wali direpresentasikan memiliki ideologi membolehkan bermain dan mendengarkan musik. La Tansa juga direpresentasikan layaknya ISA yang menginterpelasi Band Wali zsebagai subjek ideologi membolehkan bermain dan mendengarkan musik.

Film juga menampilkan ideologi bermain dan mendengarkan musik secara biner. Bentuk ideologi lain direpresentasikan melalui tokoh antagonis yaitu Hamzah. Hamzah ditampilkan lebih berbeda dari La Tansa dan Band Wali. Secara sinematik dan naratif Hamzah selalu ditampilkan menggunakan teknik berbeda untuk menekankan perbedaan secara ideologis.

Selain Hamzah yang antagonis, Film juga menampilkan ideologi berbeda melalui sosok ayah Fa'ank. Ayah Fa'ank ditampilkan memiliki perbedaan ideologi dengan La Tansa. Namun, dengan warna yang berbeda dari Hamzah. Ayah Fa'ank hanya menunjukkan perbedaan ideologis saja. Perbedaan ideologi ayah Fa'ank tidak memosisikannya menjadi sosok antagonis. Ayah $\mathrm{Fa}$ 'ank ditampilkan lebih negosiatif dalam menghadapi ideologi $L a$ Tansa dan Band Wali. Ayah Fa'ank dapat diargumentasikan sebagai representasi ideologi berbeda yang lebih negosiatif.

\section{DAFTAR SUMBER}

\section{Jurnal}

Budiman, H. G. "Representasi Tentara dan Relasi Sipil-Militer dalam Serial Patriot" dalam Patanjala: Jurnal Penelitian Sejarah dan Budaya Vol.10 No. 1. Maret 2018. Hlm 115-130.

Nurfaidah, R. "Konflik Internal Multikulturalisme dalam Film Good Bye Lennin". 2016, 5(2), $27 . \quad$ doi: 10.17510/paradigma.v5i2.55.

Poyk, S. D. M., \& Pandjaitan, Y. A. "Representation of Indonesia in Wonderful Indonesia's Feeling is Believing Tourism Advertisement: a 
Critical Discourse Analysis". 2016, 6(1), 21. doi: 10.17510/paradigma.v6i1.84

\section{Buku}

Althusser, L. 2008.

On Ideology. London: Verso.

Azra, A. 1997.

Pesantren: Kontinuitas dan Perubahan. dalam N. Madjid (Ed.), Bilik-Bilik Pesantren. Jakarta: Paramadina.

Barker, C. 2004.

The Sage Dictionary of Cultural Studies. London: Sage Publication Ltd.

Dhofier, Z. 1994.
Tradisi Pesantren: Studi Tentang Pandangan Hidup Kyai. Jakarta: LP3ES.

Durham, M. G., \& Kellner, D. M. 2001. Media and Cultural Studies: Wiley.

Eagleton, T. 1991.

Ideology : an Introduction. London: Verso.

Hall, Stuart. 1995.

The Whites of Their Eyes: Racist Ideologies and the Media. dalam G. Dines \& J. M. Humez (Eds.), Gender, Race and Class in Media: a text-reader. Thousand oaks: Sage.

$$
2003 .
$$

The work of representation. dalam S. Hall (Ed.), Representation: Cultural Representations and Signifying practices (hlm. 13-74). London: Sage.

Hammer, R., \& Kellner, D. 2009. Media/cultural Studies: Critical Approaches: Peter Lang.

Majid, N. 1997.

Bilik-bilik pesantren : sebuah potret perjalanan. Jakarta: Paramadina.

Pratista, H. 2008.

Memahami Film: Homerian Pustaka.

Villarejo, A. 2006.

Film Studies The Basics. New York: Routledge.

\section{Internet}

Nagaswara. 2010. Wali Cetak Rekor dengan RBT. diunduh Tanggal 4 Juli pukul 22.30 WIB., 2018, dari http://www.nagaswara.co.id/berita/detail /4/wali-cetak-rekor-dengan-rbt

Siregar, A. S. 2011. Flick Review : Baik Baik Sayang. diunduh Tanggal 07 Agustus pukul 22.24 WIB, 2018, dari http://www.flickmagazine.net/review/50 1-baik-baik-sayang.html. 
